\title{
Declinaciones de la reacción eclesiástica contra la Revolución francesa en España (1789-1808)*
}

\author{
Andoni Artola Renedo ${ }^{1}$ \\ Universidad del País Vasco / Institut d'Histoire de la Révolution Française \\ andoni.artola@ehu.eus
}

\author{
Antonio Calvo Maturana ${ }^{2}$ \\ Universidad de Málaga \\ antonio.calvo@uma.es
}

RESUMEN: El objetivo de este trabajo es estudiar la respuesta de la Iglesia a la amenaza planteada por la Revolución francesa. Con tal fin, se utilizarán fuentes impresas y documentos de la época que nos permitirán conocer las diferentes posturas adoptadas por el clero español, siempre desde el punto de vista de la reacción. Así, se desarrollarán cuatro epígrafes que intenten abarcar la complejidad del pensamiento eclesial a partir de 1789. El primero, se dedicará al pensamiento contrailustrado, ya existente en las décadas previas, que verá en las Luces y la revolución a un solo rival. El segundo se centrará en la tentativa de renovación de la sinergia entre el poder eclesiástico y el monárquico, producida en los textos de los eclesiásticos más cercanos al poder, generalmente más próximos

* Andoni Artola es miembro del proyecto I+D financiado por el Ministerio de Economía, Industria y Competitividad con título: «El proceso de la modernidad. Actores, discursos y cambios de la sociedad tradicional a la revolución política liberal» (HAR2013-48901-C6-4-R), del Grupo de Investigación del Sistema Universitario Vasco IT896-16, Sociedad, poder y cultura (siglos XIV a XVIII) y beneficiario de una ayuda para el perfeccionamiento del personal investigador del Gobierno Vasco. Antonio Calvo es miembro de los proyectos I+D financiados por el Ministerio de Economía, Industria y Competitividad con los títulos: «Liberalismo y antiliberalismo en España e Hispanoamérica, 1780-1840: discursos, actores y prácticas» (HAR201342563-P) y «La cultura literaria de los exilios españoles en la primera mitad del siglo XIX, CLEX 19» (FFI2013-40584-P).

${ }^{1}$ ORCID iD: http//orcid.org/0000-0002-5588-2392.

2 ORCID iD: http//orcid.org/0000-0002-7510-212X. 
también a las Luces. El tercer epígrafe pone de manifiesto cómo un sector de la Iglesia comenzó a experimentar un proceso de desafección hacia el monarca absoluto y a acercarse a posturas ultramontanas. Finalmente, el cuarto apartado se centra en el cardenal Lorenzana como ejemplo de ese proceso. La conclusión de este artículo es que el pensamiento reaccionario español fue, ya en 1789, mucho más complejo de lo que la historiografia ha percibido tradicionalmente y que ni fue absolutamente oscurantista ni totalmente afecto a la monarquía.

\section{Palabras Clave: Absolutismo; Contrarrevolución; Ilustración; Fer- nando Ceballos; Antonio Tavira; Antonio Loren- zana.}

\section{The ecclesiastic reaction to the French Revolution in Spain (1789-1808)}

ABSTRACT: This essay studies how the Catholic Church reacted to the threat of the French Revolution. Manuscripts and primary sources of this period are studied in order to identify the different positions adopted by the Spanish reactionary clergy. Four main epigraphs will be developed with the intention of covering the complexity of the ecclesiastical thinking landscape from 1789. The first one will focus on the traditional enemies of the Enlightenment, which considered that revolution was a consequence of this movement. The second one will analyse the restoration of the alliance between throne and altar addressed by those clerics who were not only closest to power, but also generally the most enlightened. Thirdly, we will see how a sector of the Spanish clergy started to feel disillusioned with the king and his absolutist policies, and found consolation in the Pope (in a sort of Ultramontanism). Finally, the last epigraph will study the case of one of these disaffected clerics, Lorenzana, Archbishop of Toledo. The conclusion of this article is that Spanish reactionary thinking after the French Revolution was much more complex than previously thought. Not every reactionary cleric was against the Enlightenment, nor were all the reactionary clergy favour to the king.

KEY WORDS: Absolutism; Counter-Revolution; Enlightenment; Fernando Ceballos; Antonio Tavira; Antonio Lorenzana.

CÓMO CITAR ESTE ARTÍCULO/CITATION: Artola Renedo, Andoni y Calvo Maturana, Antonio, «Declinaciones de la reacción eclesiástica contra la Revolución francesa en España», Hispania, 77/256 (Madrid, 2017): 437-469. doi: 103989/hispania. 2017.013.

\section{INTRODUCCIÓN}

Como es sabido, las reacciones contra las manifestaciones más radicales de la Ilustración formaron en buena medida el vivero en el que iba a nutrirse el argumentario contrarrevolucionario. Hay que ser prudentes, sin embargo, 
ante la tentación de establecer una filiación lineal entre ambos fenómenos. Si las Luces fueron un fenómeno heterogéneo, de desarrollo discontinuo, caracterizado más por los solapamientos e interferencias entre diversas tendencias que por su unicidad, tampoco sus némesis fueron unívocas ni tuvieron objetivos comunes claramente fijados ${ }^{3}$. Por ello, merece la pena estudiar las declinaciones de esa contrailustración en su variada complejidad ${ }^{4}$. Las investigaciones de las dos últimas décadas han puesto el acento en la heterogeneidad de esas expresiones reactivas contra las Luces que, desde la historia de las ideas más convencional, se habían visto reducidas a un patrón de oposición binaria que ocultaba una rica paleta de matices ${ }^{5}$. En efecto, tanto la contrailustración (primero), como la contrarrevolución (después), se impregnaron de los argumentos, las nociones y los conceptos manejados por sus contrarios en el curso de su relación dialéctica ${ }^{6}$. Cada parte modificaba, así, algunos elementos de su discurso de partida para hacerse inteligible en la disputa. La asunción historiográfica de esta retroalimentación, que sustituye al énfasis sobre la dimensión puramente reactiva de tales idearios, comporta la redefinición parcial de los objetivos de estos: ni los oponentes de las Luces, ni los enemigos de la revolución buscarían el mero restablecimiento de una situación que sabían irrecuperable ${ }^{7}$, sino que propondrían proyectos alternativos, sistemáticos, de los que todavía tenemos un conocimiento superficial.

Deberíamos comenzar a ver el inicio del siglo XIX como un periodo de múltiples posibilidades de desarrollo ulterior que, por diversas razones, se

3 Véase al respecto MACMAHON, 2001; MASSIEU, 2000: 393-418. ARMENTEROS, 2013. COMPAGNON, 2005: 44-66.

4 Preferimos el término de «contrailustración» al de «antiilustración» retomando la distinción, formulada por Claude Mazauric, entre la contrarrevolución (conjunto de estrategias políticas estructuradas en un proyecto global caracterizado por su elitismo) y la antirrevolución (reacciones espontáneas, sin fundamento político ni contraproyecto global, originadas en el descontento popular); MAZAURIC, 1987. GENGEMBRE, 1989: 82-86. No hay una conceptualización satisfactoria que distinga el contenido de cada uno de los términos, que son, por otra parte, construcciones retrospectivas elaboradas en el siglo XX. En cualquier caso, recurriremos también al más apropiado término de "antifilosofía", ya usado en el siglo XVIII, en tanto que designa con mayor precisión la reacción contra algunas expresiones de las Luces por autores que, en su confrontación con estas, se habían visto forzosamente impregnados del espíritu ilustrado. MASSEAU, 2000. ZAGANIARIS, 35 (2009).

5 CHAPPEY, 2005. MASSEAU, 2000: 7-14

6 En este sentido, POCOCK, 20/1 (1999) estima que la contrailustración puede ser concebida como una corriente de la propia Ilustración. STERNHELL, 2006: 14, hace una afirmación en el mismo sentido, aunque en una interpretación discutible estima que estas reacciones contrailustradas forman una suerte de altermodernidad que contiene la semilla de los totalitarismos del siglo $\mathrm{XX}$.

7 Como ha escrito LÓPEZ ALÓS, 2011: 48, la contrarrevolución «implica una superación de las condiciones potencialmente revolucionarias, no la vuelta al momento inmediatamente anterior a la crisis»». 
vieron abortadas ${ }^{8}$. Esta perspectiva nos permitiría salir de la linealidad teleológica con la que tendemos a observar el comienzo de aquella centuria, sin ignorar los proyectos fracasados o inacabados en cuya plausibilidad sus portadores, sin embargo, creyeron plenamente. Pero para dar cuenta de estos escenarios posibles conviene conocer los precedentes de los que se alimentaron. Con este ánimo, estudiamos en el presente texto distintas variaciones de la reacción eclesiástica contra el ciclo revolucionario francés durante la última década del siglo XVIII. La diversidad de corrientes eclesiológicas y teológicas que atravesaban el estamento clerical impidieron (al contrario de lo que frecuentemente se ha defendido) la formación de un frente unívoco ante las Luces. Huelga decir que tampoco se formó ante la Revolución francesa ${ }^{9}$.

En primer lugar, se estudiará la reactivación del espíritu antifilosófico del jerónimo Fernando Ceballos en la España posterior a 1789. A continuación, prestaremos atención al clero reformista, regalista e ilustrado, que por lo general mantendría una relación más estrecha con el trono, para observar cómo defendió a la Iglesia y a la Monarquía de los ataques exteriores sin traicionar su fe en las Luces. Finalmente, analizaremos, en dos apartados, otra configuración específica de ese pensamiento que, difuminada por su inclusión en el segundo bloque del esquema dicotómico revolución / reacción, no ha recibido en nuestra opinión la atención que merece: el de la crítica altoclerical de la acumulación del poder en el monarca, seguido del desengaño de una parte del episcopado que tuvo por consecuencia su progresiva desvinculación de la Corona y la emergencia de un incipiente ultramontanismo ${ }^{10}$.

\section{El eSPíRITU DEL PADRE CEBALlos}

El ataque en España a los apóstoles europeos de la igualdad y la libertad es previo a la Revolución francesa. La publicación de las traducciones de obras firmadas por apologistas como Claude-François Nonnotte, Nicolas-Silvestre Bergier y Antonio Valsecchi marca la divulgación de esta reacción contra las ideas del siglo. Estos enemigos declarados de las Luces denunciaban y demo-

8 Véanse las pertinentes reflexiones al respecto de FUREIX, 2014: 5-20; FUREIX y JARRIGE, 2015.

9 Dejamos para otra ocasión un estudio interesante como el de la "reacción ilustrada", aunque este colectivo ya aparece representado en este trabajo pues también hubo, evidentemente, clérigos ilustrados.

10 En adelante, ultramontanismo ha de entenderse como un movimiento de reafirmación, centralización, y expansión del poder pontificio sobre el mundo católico. Como se ha de ver, aunque los prefigura, no presenta a finales del siglo XVIII los caracteres de fidelidad absoluta e indiscutible a la autoridad jurisdiccional y doctrinal de la Santa Sede que lo caracterizarían durante el siglo siguiente, y por lo tanto utilizamos la noción como "tipo ideal". 
nizaban a los llamados "nuevos filósofos" (Voltaire y Rousseau principalmente), calificándolos de campeones de la impiedad, la incredulidad y el ateísmo, considerándolos herederos de los protestantes como enemigos del catolicismo y conspiradores, en clave no pocas veces apocalíptica, contra un orden sancionado por la providencia ${ }^{11}$.

Junto a las traducciones de sus obras, estos ideólogos franceses e italianos encontraron su eco en escritores españoles que aplicaron sus teorías de la conspiración a la situación del país. Pero, cabe preguntarse, ¿era real esta amenaza? La sensación general de los historiadores es que no. Aunque Rousseau, Voltaire y Montesquieu eran conocidos, e incluso admirados (especialmente el último), por algunos intelectuales españoles, no habían llegado a crear escuela. Además, el carácter moderado y pragmático de la Ilustración española, y el control férreo que el Estado, la Inquisición y la autocensura ejercían sobre la imprenta, minimizaron su presencia en el panorama literario del último tercio de siglo.

En consecuencia, los frailes antifilosóficos no estaban denunciando una amenaza real de las ideas de la Ilustración radical en España; más bien se sirvieron de estos clamores apocalípticos como argumento de refuerzo para insistir en lo que venían haciendo años atrás. Esto es, trabar todo intento de avance del pensamiento científico y laico en el país. Por su perspectiva contraria al racionalismo y sus argumentos de orden estrictamente religioso, estos autores han de diferenciarse de otros -que trataremos en el próximo apartadoque no defendieron un "apagado" de las Luces en su totalidad, sino que advirtieron de sus peligros si no eran convenientemente controladas.

Pero el poder político de los ilustrados españoles y el impulso a ciertas Luces en tiempos del idealizado Carlos III fueron muy relativos. En este sentido, no se puede ignorar el apoyo expreso que dos reformistas como Campomanes y Floridablanca hicieron de las dos grandes obras oscurantistas de las dos décadas previas a la Revolución francesa. Así, La falsa filosofía (1774), de fray Fernando Ceballos, contiene una dedicatoria al primero de 26 folios instándolo, como primer magistrado de la nación, a proteger a la religión católica y las regalías del monarca. Por su parte, Vicente Fernández Valcárcel encomendaría los Desengaños filosóficos (1787) a Floridablanca ${ }^{12}$. En ambas dedicatorias se aprecia un intento de sus autores "antifilosóficos" de maridar el objetivo de la obra con las ínfulas reformistas de sus homenajeados.

La incoherencia que suponía el apoyo de este tipo de autores para un rey y un gobierno que basaban cada vez más su prestigio interno y externo en su talante ilustrado (solo hay que leer los elogios publicados a la muerte de Carlos III) acabó manifestándose en la persona del padre Ceballos. Sus duras

11 HERRERO, 1971: 35-37.

12 FERNÁNDEZ DE VALCÁRCEL, 1787-1797. 
críticas contra la traducción al castellano, en 1774, de la famosa obra de Beccaria, De los delitos y de las penas, supusieron la reacción del Consejo de Castilla contra el jerónimo (obligándole a un «perpetuo silencio» en 1782) y contra sus ideas: la publicación del séptimo tomo de La falsa filosofía, que proyectaba hasta doce, fue paralizada, y los seis primeros volúmenes requisados. Los censores del Consejo calificaron en 1776 y 1781 a Ceballos como «miserable escritor» y a su obra como «ridícula y despreciable». Victoria pírrica para las Luces, pues corrió pareja a la prohibición inquisitorial del libro de Beccaria en $1777^{13}$.

No desaparecieron, sin embargo, los ecos de estos autores contrailustrados, ni siquiera en la década de 1780, en la que publicaciones como El Censor (aun considerando sus problemas con la censura) demostraron cierta permisividad con las Luces. En 1788, por ejemplo, se tradujo la Defensa de los puntos más interesantes a la religión acometidos por los incrédulos, de Nonnotte.

Con la Revolución francesa, se produjo en España una revigorización del espíritu antifilosófico ${ }^{14}$. El propio secretario del despacho de Estado lo manifestó con las medidas que han dado en conocerse como "el pánico de Floridablanca", marcadas por el establecimiento de un cordón sanitario con Francia, un recrudecimiento de la censura (de la mano del cierre de casi todos los periódicos) y la revigorización de la actividad inquisitorial.

Tras el intento de mantener a los españoles ajenos a las noticias de lo sucedido en Francia, la ejecución de Luis XVI y la posterior declaración de guerra obligaron al gobierno de Carlos IV a cambiar de estrategia e iniciar un ataque a gran escala contra las ideas revolucionarias, de notorio eco clandestino en el país. Son años en los que la imprenta fomentó el resurgimiento de la ideología contrailustrada. Ya en 1793 apareció la refutación de Nonnotte al Diccionario filosófico de Voltaire, mientras que desde los púlpitos se predicaba la cruzada contra el nuevo "infiel".

Los autores antifilosóficos vivieron, coincidiendo con la guerra contra la Convención, un periodo de cierto éxito. La obra contrarrevolucionaria más significativa durante estos años fue El soldado católico en guerra de religión (1794), de fray Diego de Cádiz, El libro recoge a la perfección la idea del conflicto como guerra de religión que obliga al soldado en conciencia por la defensa del orden divino, idea tradicional que se había mantenido vigente en el XVIII. Este fraile, cuyos efectivos y efectistas sermones de tono profético y apocalíptico lo habían hecho ya célebre en la década anterior, se había señalado como enemigo de las Luces al acusar de herejía al reformista Lorenzo Normante en 1786. El predicador caería en desgracia en 1800 tras ser delata-

13 ROBLEDO, 2012.

14 Nuevo despliegue de la antifilosofía que tuvo su paralelo en el resto de Europa. MASSIEU, 2000. 
do al Santo Oficio por cuestionar las regalías eclesiásticas del monarca, hecho del que había sido ya acusado previamente ${ }^{15}$.

El patrón seguido en los casos de fray Diego de Cádiz y el padre Ceballos manifiesta la desconfianza del gobierno hacia los predicadores más barrocos y conservadores, que eran un arma de doble filo para la monarquía borbónica, cuya política regalista e ilustrada chocaba con los planteamientos teocráticos de estos religiosos. Es muy probable que la mayoría de ellos se sintieran traicionados por el rey con la firma de la Paz de Basilea y el consiguiente Tratado de San Ildefonso, que hacía primar las necesidades geoestratégicas del país sobre los argumentos religiosos. La influencia adquirida durante el conflicto y la costumbre de "opinar" sobre las relaciones hispano-francesas podía convertir a estos predicadores en un peligroso enemigo ahora que Carlos IV se había aliado con la república regicida. La guerra de la Independencia daría también una nueva vida a El soldado católico, que fue reeditado al menos en 1813, 1814 y 1815.

El discurso de El soldado católico coincide con el del resto de maestros reaccionarios, al negarse a considerar a los nuevos filósofos, a los revolucionarios y a la revolución en sí como algo nuevo. En este sentido, el uso de la Historia como magistra vitae supone un ancla de inmovilismo, ante la idea de progreso; una idea de eternidad contrapuesta al mensaje de revolucionario de la apertura de una nueva era. Este recurso narrativo ayuda a localizar en todas las épocas de la Historia personajes y eventos que son utilizados para establecer paralelismos -tanto positivos y negativos- con el presente, realizando una interpretación retrospectiva de los hechos que diera sentido al trauma revolucionario. Dos periodos históricos como la Reconquista o las guerras de religión devienen, así, extraordinarias canteras interpretativas para los contrarrevolucionarios españoles ${ }^{16}$.

En estos mismos años, el proceso inquisitorial de Ramón de Salas, profesor de la Universidad de Salamanca denunciado por un anónimo enviado a Floridablanca en 1792, simbolizó la caza de brujas contra los intelectuales más progresistas en un nuevo intento de los sectores contrailustrados de aprovechar la coyuntura para ajustar cuentas pendientes con las Luces.

En el contexto de los ataques oscurantistas a los estudios filosóficos en general (las cátedras de derecho natural fueron suprimidas en 1794), y de los impartidos en la Universidad de Salamanca en particular, hay que situar el "renacer" del padre Ceballos, que mantuvo correspondencia con Godoy entre 1794 y 1796. Tras el regicidio francés, este monje, que había pronosticado los mayores males para la monarquía de continuar las Luces sus progresos, debía de sentir que la Historia le había dado la razón. Aprovechando la coyuntura, y tras su experiencia como visitador de la Orden de los Jerónimos, remitió a

15 LÓPEZ-CORDÓN, 1978.

16 RAMÓN SOLANS, 2012: 215-243. 
Godoy un Remedio permanente de las Universidades y modo práctico de establecerlo, donde apostaba por emprender un camino contrario a la reforma carlotercerista y poner a cada uno de estos centros bajo el control del obispo respectivo, y a todos bajo la jurisdicción de una Dirección General de Estudios integrada sobre todo por clérigos regulares. Nostálgico de los tiempos de Felipe II, Ceballos apoyaba su decreto de prohibición para que los españoles estudiasen en el extranjero. A pesar de la aparente receptividad de las altas instancias (del gobernador del Consejo de Castilla, Fernández Vallejo, e incluso del rey, según intuye R. Robledo), el fraile nunca vería aprobado su plan, ni publicados sus manuscritos. Habría que esperar a la Guerra de la Independencia para el resurgir de sus obras en la imprenta ${ }^{17}$ (que no entre el público lector, como comentaremos en breve).

Superados el miedo inicial al contagio revolucionario y las urgencias bélicas, el espíritu de cruzada dejó de tener sentido. En manos de Godoy, el reformismo volvió (quizás con más fuerza) al gabinete español, y la alianza con Francia (Tratado de San Ildefonso, 1796) hizo que la galofobia de años atrás fuese incómoda en términos de política exterior.

Subsistirían, empero, algunos ecos del espíritu del padre Ceballos en los meses siguientes. En 1797, se publicó el tomo IV de los Desengaños filosóficos de Valcárcel, quien reconocía en el prólogo haber cambiado el plan de su obra tras el estallido de la Revolución francesa. Mientras la tendencia de las producciones de las Sociedades Económicas y las academias reales es, a finales de siglo, la de dar al factor religioso un papel secundario, representando al rey como el primer patriota, Valcárcel devolvía el componente teocrático al primer plano. Es el caso del elogio del autor a las persecuciones religiosas de Carlos III tras la conquista de Menorca para purificarla de «toda infección judía, mahometana y protestante», ya que «en el juicio de un Príncipe verdaderamente Católico un poco mas de población, de comercio y tráfico, nada importa en comparación de la seguridad, y pureza de la religión» ${ }^{18}$. El menosprecio de Locke y Descartes por parte del mismo autor, y frases como, «mejor nos es dormir que despertar para tales paradojas» dan la razón a Javier Herrero al situar a estos religiosos en el espectro más inmovilista del pensamiento español de la época ${ }^{19}$.

La Iglesia tuvo aún, durante el reinado de Carlos IV, una nueva ocasión para la confrontación. Se trata del ascenso al poder del gabinete filojansenista a finales de siglo, periodo durante el cual la toma de medidas de alta carga regalista y episcopalista como la desamortización de 1798 o el famoso decreto de Urquijo de septiembre de 1799 (por el que el monarca se arrogaba atri-

17 ROBLEDO, 2012.

18 FERNÁNDEZ DE VALCÁRCEL, 1787-1797, vol. IV: 276.

19 HERRERO, 1971: 110-113. 
buciones pontificias, aprovechando el vacío existente en la silla de San Pedro), provocaron una reacción de un amplio sector eclesiástico que comprendió a los clérigos más conservadores, claro está, pero también a algunos reformistas que habían venido colaborando con el proyecto borbónico, desencantados con este por culpa de los acontecimientos posteriores a la Paz de Basilea.

Los años finales del reinado de Carlos IV, suponen, sin que se truncase el reformismo gubernamental (ni siquiera en el seno de la Iglesia, como demuestran los intentos de reforma del clero regular de Luis de Borbón a partir de la bula Inter graviores), un periodo de desconfianza generalizada hacia el poder político y de reagrupamiento de las fuerzas inmovilistas en torno a la figura de Fernando VII. Aunque silenciado políticamente, el clero más conservador seguía teniendo un fuerte predicamento. Un informe de Francisco Bruna a al secretario del despacho de Gracia y Justicia José Antonio Caballero, fechado el 24 de enero de 1802, informaba de la revitalización del interés del público por las obras del padre Ceballos, que habían pasado de «andar en el baratillo» o ser repartidas en los conventos a cuenta de misas, a ser muy cotizadas, «de modo que en el día se halla rarísimo ejemplar, que se vende muy caro» ${ }^{20}$.

El descrédito de los filojansenistas (evidenciado en el pase regio a la bula Auctorem fidei y en la desgracia de personajes como Jovellanos) dio voz a los más críticos con este sector, como Lorenzo Hervás y Panduro. Exjesuita, enemigo acérrimo de los jansenistas, Hervás ya había defendido en su Historia de la vida del hombre (1789) que estos habían sido los aliados de los filósofos en la preparación de la Revolución francesa ${ }^{21}$. Este autor, cuya amplia producción literaria no deja duda alguna sobre su condición ilustrada (los propios ultramontanos rechazaron sus obras por ser excesivamente filosóficas), es también uno de los grandes artífices del maniqueísmo contrarrevolucionario español. Para él, el siglo de la extinción de la Compañía no podía ser menos que la centuria del apocalipsis ${ }^{22}$. En 1794, escribió sus Causas de la Revolución de Francia y medios de que se han valido para efectuarla los enemigos de la revolución y el estado, en las que anticipaba la tesis complotista de Barruel ${ }^{23}$. La censura negativa del inquisidor Joaquín Lorenzo Villanueva (el futuro liberal acusó a Hervás de "filósofo") y la alianza con Francia hicieron que la obra no fuese publicada hasta $1803^{24}$, momento de decadencia del influjo filojansenista.

20 AHN, Consejos, leg. 11.284/2, cit., por ROBLEDO, 2015: 219-236.

21 HERRERO, 1971: 151.

22 HERRERO, 1971: 153.

23 RAMÓN SOLANS, 2012: 232.

24 Es la fecha que aporta Herrero, si bien la edición más antigua que posee la Biblioteca Nacional es de 1807. 


\section{EL ALTAR EN DEFENSA DEL TRONO}

En 1799 el exjesuita Antonio Eximeno publicó El espíritu de Maquiavelo, una respuesta al elogio que Juan Bautista Baldelli había hecho del florentino en 1794. En una de las disertaciones de Eximeno, la dedicada a refutar la opinión de Maquiavelo sobre el poco valor de los soldados cristianos, el español estimaba que lo importante en un ejército es la capacidad de sus jefes y la sabiduría de sus ordenanzas, añadiendo que «no puede tener influjo el alborotado entusiasmo popular, y mucho menos la religión, en la cual, durante el calor de la batalla, ninguno de los combatientes piensa» ${ }^{25}$.

Cinco años después de la publicación del Soldado católico y de la predicación de una cruzada contra los revolucionarios, un religioso afirmaba que este tipo de mensajes (al contrario de lo defendido por el propio Cadalso en relación al mito de Santiago) eran inútiles. No es de extrañar, y más teniendo en cuenta lo poco que gustaba a los poderes fácticos absolutistas cualquier mención a Maquiavelo, que la Inquisición prohibiese la obra en 1800.

Este ejemplo demuestra hasta qué punto dentro del seno de la Iglesia, aun habiendo un rechazo generalizado de partida al credo revolucionario ${ }^{26}$, se pueden encontrar diferentes modelos de contrarrevolución y de contrarrevolucionarios. Las distintas respuestas al reto de 1789 se corresponden, en ocasiones, con las divisiones previas a las que se ha aludido en la introducción. En lo que toca a los eclesiásticos más en contacto con el fenómeno ilustrado, observamos una serie de argumentos de sesgo más racional, de tono mucho más moderado y menos maniqueo.

En el siglo XVIII, con el incremento del control sobre la jerarquía eclesiástica, la creación de seminarios y la expulsión de una orden afecta a la Santa Sede como era la jesuita, el Estado borbónico buscó la formación de un clero fiel que colaborase con él, ya no solo en el mantenimiento del statu quo, sino también en las reformas emprendidas para la optimización de los recursos del país desempeñando dos papeles, como controladores de las conciencias del pueblo que tenía que acatarlas y como ejecutores de las mismas desde puestos tanto eclesiásticos como administrativos ${ }^{27}$. Es cierto que la quimera reformista solo pudo captar a una parte del clero, siendo el regular especialmente esquivo, pero tan solo el reinado de Carlos IV nos ofrece nombres como los de Tavira, Díaz de Valdés, Llorente, Villanueva, Estala o Melón, que son buena muestra de lo dicho.

El clérigo ilustrado por excelencia es asociado, con mayor o menor acierto, al "jansenista", término que -como es bien sabido- no agrupaba a finales del XVIII a los seguidores de Jansenio y a su doctrina teológica de la gracia, sino

25 EXIMENO, 1799: 93-94.

26 Si bien hubo excepciones, como la del famoso abate Marchena.

27 CALVO MATURANA, 2011. 
a un grupo de religiosos y laicos que abogaban por una religiosidad interior, una reforma de la Iglesia, una mejor formación de sus miembros y un regreso al episcopalismo pretendidamente originario en detrimento del poder pontificio. El jansenismo, por tanto, casaba coyunturalmente con el regalismo y el reformismo borbónicos, y alcanzó una considerable influencia durante la primera década del reinado de Carlos IV a pesar de que otros clérigos los consideraron una quinta columna de los filósofos del siglo, además de herederos de los reformistas luteranos ${ }^{28}$.

Antonio Tavira, nombrado obispo de Salamanca durante el corto periodo en el que Jovellanos fue secretario de Gracia y Justicia, es un buen ejemplo de clérigo jansenista, que debió su exitosa carrera más a la actividad intelectual y a la Corte, que a la trayectoria pre-episcopal que pasaba por las curias de los prelados o los cabildos catedralicios ${ }^{29}$. Defendió al trono y al altar ante la amenaza revolucionaria, pero lo hizo de una forma distinta, diferenciando claramente Ilustración y revolución, y justificando la diferenciación entre el presente epígrafe y el anterior.

Considerado por muchos de sus contemporáneos como «el mayor predicador del siglo» ${ }^{30}$, este alto representante de la "ilustración católica" española fue autor de varios discursos en los que trató de fomentar la obediencia al rey como padre de la patria. El espíritu reformista del obispo se puede apreciar en el informe que le había solicitado el Príncipe de la Paz con ideas para «fomentar la industria, agricultura y comercio».

Sin tapujos, renunciando a la autocomplacencia apologética, Tavira consideraba «innegable el atraso que padecemos». La solución para este atraso, pasaba, según el autor por la educación, focalizada en la mejora tanto del conocimiento científico como de la formación religiosa. En un siglo en el que cundía la «impiedad»y «la desenfrenada licencia de pensar», y en el que se habían combatido como nunca «los más ciertos y sentados principios de la religión», apostaba el prelado por lo contrario a la dogmática cerrazón: «Lo que yo no dudaré afirmar es que se acabó ya el tiempo en que se creía que la ignorancia serviría para precavernos» ${ }^{31}$.

Hemos hablado ya del proyecto de reforma de las universidades del padre Ceballos, por lo que resulta oportuno confrontarlo con las ideas de Tavira sobre la educación superior. En el citado informe, el obispo proponía la formación de una junta, igual que el jerónimo, con la diferencia de que la del primero había de estar formada por «personas escogidas entre las de mayor instrucción de todo el reino», reconocidos por su «vasta literatura» y su amor

28 HERRERO, 1971: 71-89.

29 ARTOLA RENEDO, 2013: 221 y 228.

30 SAUGNIEUX, 1986: 38.

31 TAVIRA, 1797: 143. 
a «las ciencias y artes útiles» ${ }^{32}$. La de Ceballos es también una junta de sabios, pero su espíritu es censor, el de una guardiana de la doctrina ${ }^{33}$.

Sin duda, no obstante de ser crítico con las ideas revolucionarias, Tavira aceptó la alianza de Carlos IV con Francia de mejor grado que los predicadores apocalípticos. En 1801, para apaciguar los ánimos del pueblo (al que pocos años antes le habían representado a los franceses como poco menos que el Anticristo) ante el paso de las tropas napoleónicas en dirección a Portugal, explicó a los fieles de su diócesis que el buen católico debe tender la mano a su prójimo independientemente de su credo («el idólatra, el mahometano, el hereje, todos son nuestros acreedores, y a todos debemos, según las circunstancias lo exigieren, los oficios de caridad») y que, además, «la República francesa» ya no vive «los calamitosos tiempos que siguieron a su Revolución, tiempos que ya detestan todos» en un país en el que, a pesar de la libertad de cultos, «de ocho partes las siete y media profesan la religión católica» ${ }^{34}$.

Fueron varias las defensas del trono publicadas en el reinado de Carlos IV que se pueden diferenciar del modelo del Soldado católico. La primera característica de estas obras es que pusieron el centro de atención en la obediencia al monarca por mandato divino más que en la defensa de la religión en sí. La segunda es la cercanía de sus autores a la Corona, reflejada tanto en sus carreras como en el apoyo recibido por sus obras. La tercera es el utillaje ilustrado utilizado - en mayor o menor medida- por los autores, que empleaban un tono y un vocabulario distintos a los de los autores más beligerantes e intentaban refutar de manera racional las ideas de los filósofos a los que condenaban.

Entre los tratados políticos de aquel periodo firmados por eclesiásticos destacaremos cinco: El vasallo instruido en las principales obligaciones que debe a su legítimo monarca de Antonio Vila (1792), el Catecismo del Estado de Joaquín Lorenzo Villanueva (1793), La Monarquía de Clemente Peñalosa (1793), El vasallo fiel a su Príncipe de Sebastián Sánchez Sobrino (1798) y la Verdadera idea de la Sociedad Civil, gobierno, y soberanía temporal conforme a la razón de Francisco Dorca (1803) ${ }^{35}$.

Tradicionalmente, se han venido valorando las dedicatorias desde un punto de vista unidireccional. Esto es, como elemento de adulación y búsqueda de protección por parte del autor, pero se suele obviar que dichas dedicatorias debían ser aceptadas por los homenajeados (los expedientes de imprenta están llenos, por ejemplo, de solicitudes rechazadas por Floridablanca). De manera que la concesión del permiso para la inclusión del nombre de un ministro o del mismo rey en el encabezamiento de una obra, implicaba un respaldo de la

\footnotetext{
32 TAVIRA, 1797: 143-144.

33 CEBALLOS, 1796.

34 TAVIRA, 1801: 174-175.

35 CALVO MATURANA, 2011: 51-84.
} 
autoridad al autor y a su obra ${ }^{36}$. Desde este punto de vista hay que valorar el hecho de que La Monarquía y el Catecismo de Estado estén dedicados a Carlos IV (la primera, con grabado del rey incluido ${ }^{37}$; el segundo, publicado por la Imprenta Real), y El vasallo fiel a su príncipe, a Francisco Saavedra, secretario de Estado. En cuanto a Antonio Vila, se puede apreciar en su carrera un ascenso motivado por su servicio intelectual al monarca, puesto que su obra le valió una canonjía de la catedral de Menorca ${ }^{38}$.

En las obras de Villanueva y Peñalosa, José María Portillo observó algo aplicable a las otras tres. A raíz de la amenaza revolucionaria y de las posibles filtraciones filosóficas a la teología católica, «se percibía la necesidad de reformular un principio teológico que sirviera de fundamento religioso al orden político, que indicara al vasallo católico la obligación religiosa respecto de la "constitución de Estado"»" ${ }^{39}$. Estos textos trazaron un «discurso católico antipolítico» que, además de exhortar a la obediencia por mandato divino (con evidentes ecos de Bossuet), defendía a la monarquía absoluta como el mejor de los sistemas políticos posibles. Estas obras, insistimos, se diferencian de las vistas en el apartado anterior en su objetivo político (o antipolítico), pues se centran en legitimar al monarca y en fomentar la obediencia de sus súbditos, integrando esta obediencia entre las obligaciones religiosas.

Siendo las obras de Villanueva (autor difícil de clasificar teniendo en cuenta su actividad política posterior) y Vila las más tradicionales formalmente, encontramos en las cinco citadas alusiones directas a los nuevos filósofos, así como expresas refutaciones de sus argumentos. También es común a los cinco autores el recurso al iusnaturalismo (tan importante para rebatir a Hobbes, Locke y Rousseau) para demostrar que la paternidad es el primer vínculo social del hombre que, reproducido a gran escala, da lugar a la monarquía, el más natural de los gobiernos (y vincula, claro está el cuarto mandamiento a la obediencia a los reyes). En cierta medida, al rebatir los argumentos de sus contrarios, los mencionados autores se apropiaban del utillaje conceptual que aquellos utilizaban, y lo reproducían. Aunque ninguno compartía la imagen monstruosa del poder ofrecida por Hobbes, todos corroboraron de alguna forma su diagnóstico: el hombre necesita de un gobierno fuerte que lo proteja. Esto no implica que estos tratadistas reconociesen la existencia de un pacto, ya que para ellos la voluntad humana está condicionada desde el principio por el conveniente orden social diseñado por Dios.

36 CONDE NARANJO, 2006, pp. 325-340.

37 De hecho, Peñalosa, arcediano de la catedral de Segovia, obtuvo un permiso real para ausentarse de aquella ciudad y residir en la Corte para redactar la obra (BONO GUARDIOLA, 1995: 315-321).

38 ARTOLA RENEDO, 2013: 253-254.

39 PORTILLO, 2000: 87. 
A diferencia de Vila y Villanueva, que defendieron la obligación de obedecer a cualquier monarca, aunque fuese un tirano, Peñalosa y Dorca optan por defender el carácter amable de los reyes absolutos, diferenciándolos (con ecos evidentes de Montesquieu) de los déspotas. Así, escribía Peñalosa: «cuanto dista la superstición de la religión verdadera, tanto se aparta el gobierno arbitrario de la Monarquía Absoluta ${ }^{40}$. Ambos autores, lejos de tratarlos como seguidores del Anticristo, se refirieron a los filósofos con cierto respeto, que en el caso de Peñalosa se antoja incluso admiración dentro del disentimiento con sus ideas. Así, se refería a Rousseau como «aquel espíritu observador y profundo, aquel corazón agrio que jamás pudo mirar con indulgencia el desliz más pequeño del virtuoso; aquel entendimiento, que reuniendo las calidades naturales del filósofo, ostentó en sus escritos los axiomas fuertes de un republicano» ${ }^{41}$. Las citas al Espiritu de las Leyes de Montesquieu se reparten por la misma obra.

Clemente Peñalosa es, después de Villanueva, el más conocido de los autores, por lo que no le dedicaremos mucho espacio ${ }^{42}$. Su Monarquía es el testimonio de un eclesiástico reformista, un ilustrado conservador que quiere defender a su rey recurriendo al lenguaje del siglo y a la argumentación racional, evitando, en la medida de lo posible, recurrir a la autoridad de la Biblia. No se conformaba el religioso con afianzar al sistema monárquico en las raíces de la tradición; como ha observado acertadamente Portillo, el autor identificó a la monarquía «con la modernidad», haciendo de ella el ámbito ideal para «la civilización, el desarrollo de la vida urbana y el comercio, la diversificación de la propiedad y la formación de patrimonios»y, por lo tanto, el sistema que ofrece la verdadera libertad al hombre ${ }^{43}$. El rey y el conjunto de "ciudadanos" (a menudo mencionados con términos colectivos como "patria" y "nación") conviven en tal armonía que son uno: «... el poder de la ley y toda su autoridad se deposita en un hombre solo, que moralmente es todos los demás, como único origen y término de las relaciones que estrechan el cuerpo con su cabeza y la patria con sus individuos ${ }^{4}{ }^{4}$.

En cuanto a Francisco Dorca, resulta llamativo que haya pasado tan desapercibido para los historiadores ${ }^{45}$. Este clérigo inició su trayectoria en la universidad de Cervera, donde ocupó varias cátedras, pero su carrera se vio truncada por su conocido projesuitismo. En 1778 no había pasado de canónigo de

40 PEÑALOSA, 1793.

41 PEÑALOSA, 1793: 357.

42 Vid. BONO GUARDIOLA, 1995. PORTILLO, 2000: 101-108. CALVO MATURANA, 2011: 51-84.

43 PORTILLO, 2000: 103.

44 PEÑALOSA, 1793: 88-89.

45 CALVO MATURANA, 2011: 51-84. 
la catedral de Gerona. No parece casualidad que este autor publicase la mayoría de sus obras a principios del XIX, tras la desgracia jansenista, momento que quiso aprovechar para coger el impulso de los nuevos aires políticos. En 1801 publicó un oportunista texto antigalicano, el Discurso sobre el primado pontificio, esto es, sobre el origen, naturaleza y objeto de este primado.

En 1803 vieron la luz las dos obras que más nos interesan aquí, ambas en la imprenta de Vicente Oliva, "Impresor de S.R.M.", la Verdadera idea de la sociedad civil y De las ventajas del gobierno monárquico. Francisco Dorca sorprende en sus obras por su perspectiva. En la primera de las citadas, extracta pasajes de Rousseau para señalar las contradicciones del ginebrino y probar así que el hombre es un súbdito bajo el "pacto social" 46 o la importancia de la religión ${ }^{47}$. En De las ventajas del gobierno monárquico, reconoce su intención de emular El espíritu de las leyes de Montesquieu.

Fijémonos finalmente en el franciscano fray Sebastián Sánchez Sobrino ${ }^{48}$, cuya obra más destacable en defensa del trono es El vasallo fiel a su príncipe, publicada en $1798^{49}$. El objetivo del libro es manifestar «los estrechos vínculos de amor, de obediencia y de fidelidad que nos ligan a nuestro reyes y señores naturales». Aunque el autor no evitase la tentación de considerar el XVIII como un siglo «corrompido» y se refiriese al conjunto de autores que conspiraban contra el altar y el trono como «nuevos filósofos» y herederos de la herejía protestante, encontramos en la obra varios elementos que la diferencian de los escritos más reaccionarios del siglo y que ponen de manifiesto el talante ilustrado de su autor, comenzando por la dedicatoria al secretario interino de Estado Francisco Saavedra, al que llama «condiscípulo» por haberse formado ambos en el convento de San Antonio Abad de Granada bajo la tutela del historiador de la literatura fray Rafael Rodríguez Mohedano. El propio Saavedra contaría más tarde cómo la guía del religioso y la asistencia a su tertulia lo habían iniciado en lecturas como la del padre Feijoo ${ }^{50}$.

Dicho talante se refleja en El vasallo fiel a su príncipe de muchas maneras, empezando por aspectos formales como el tono moderado del texto (que no demoniza a los «nuevos filósofos») o la breve extensión de la obra, adaptada al «genio moderado de nuestro siglo (...) amante de la brevedad» (comúnmente denunciada, por superficial, por los enemigos de las Luces). Un razonamiento propio de los nuevos tiempos se puede encontrar en los argumentos esgrimidos por el autor para la obediencia al monarca. El principal de ellos,

46 DORCA, 1803a: 17-19.

47 DORCA, 1803b: 39-40.

48 CALVO MATURANA, 2017.

49 SÁNCHEZ SOBRINO, 1798.

50 VALVERDE TERCEDOR, 2015: 9. 
por supuesto, se encuentra en la conciencia ${ }^{51}$, puesto que se trata de un mandato divino; pero, si «esas leyes sagradas no bastasen a conciliarles nuestra veneración y respeto», pregunta Sánchez Sobrino, «¿no debería bastar nuestro amor a la Patria, de la cual [los reyes] son padres?». En la misma línea, apreciada también en La Monarquía de Peñalosa, y seguida por los oradores de las Sociedades Económicas de Amigos del País, el autor hace de la patria un colectivo que marca el común interés entre el rey y sus vasallos: «Este dulce vínculo nos une tan estrechamente con ellos [los monarcas], que nos hace personales su majestad, su decoro, sus guerras, sus alianzas. Sus derechos, sus pérdidas, sus ventajas, todo nos es común mediante el amor a la Patria». Ese vínculo patriótico, aunque era más próximo a la dieciochesca idea de bien común que al nacionalismo decimonónico, tiene ya «su origen en el corazón del vasallo» ${ }^{52}$ (aunque el fraile no se cansase de puntualizar que «la fidelidad a los reyes no es una virtud puramente civil o política, sino cristiana y de conciencia» ${ }^{53}$ ).

Los autores de cabecera de Sánchez Sobrino en El vasallo fiel a su príncipe no son aquellos reconocidos por Herrero como los padres del pensamiento reaccionario dieciochesco. Además de las acostumbradas referencias a autores latinos, a las Sagradas Escrituras y a Santo Tomás, encontramos citas a intelectuales eclesiásticos de un perfil distinto, tales como Juan Ginés de Sepúlveda, Diego Saavedra Fajardo, el jansenista Claude-Pierre Goujet y el probabiliorista Daniello Concina, claros defensores todos de la soberanía regia, pero con argumentaciones derivadas del intelecto, no de las entrañas ${ }^{54}$.

Para conocer un poco mejor al personaje, se puede rastrear brevemente su obra en los años siguientes. En 1813, publicó bajo pseudónimo un periódico semanal titulado El ciudadano imparcial, donde la imparcialidad brilla por su ausencia puesto que se trata de un claro vehículo para la deslegitimación de los liberales de las Cortes. Pero Sánchez Sobrino no era un "servil" recalcitrante. A su familiarización con el lenguaje del momento ("nación", "patria", "conciudadanos"...) hay que unir que no critica la ley de libertad de imprenta en su totalidad, sino cuando se vulnera para hablar de asuntos religiosos. Igualmente, reconoce la necesidad de una reforma del clero secular y regular, pero condena lo que considera una persecución contra la Iglesia y sus bienes.

En definitiva, la contrarrevolución española contó, también, con autores eclesiásticos que no dudaron en tachar a los filósofos mentirosos, embaucado-

51 Vid. por ejemplo, SÁNCHEZ SOBRINO, 1798: 81-85.

52 SÁNCHEZ SOBRINO, 1798: 110.

53 SÁNCHEZ SOBRINO, 1798: 86.

54 Es cierto que Sánchez Sobrino cita varias veces al juez inquisidor de Giordano Bruno y Galileo, el contrarreformista Roberto Belarmino, un intelectual, sin duda, pero que puede ser asociado a la batalla de la Iglesia contra los avances científicos. 
res e impíos, pero que separaron lo ilustrado de lo revolucionario; que leyeron a estos autores en lugar de citarlos de segunda mano; y que respondieron a sus argumentos desde una paradójica tradición renovada acorde con las circunstancias.

\section{EL DOBLE FILO DE LA CRÍTICA A LA REVOLUCION FRANCESA}

El alcance de la expansión dieciochesca del poder monárquico se revelaría en toda su operatividad al comenzar la Revolución francesa, que transformó las relaciones de los súbditos con el poder soberano tanto allí donde logró tener éxito como donde se reaccionaba contra ella. Después de 1789 el poder regio se vería obligado a reconsiderar, como respuesta a la rompedora idea de la soberanía nacional, los vínculos que le unían con los súbditos. La guerra contra la Convención sería la ocasión de pulsar esta vinculación poniendo a prueba la capacidad de movilización de recursos con los que, después de varias décadas de expansión, contaba la monarquía ${ }^{55}$.

La Corona contaba en esta tarea con la cooperación de una alta clerecía a la que pidió que actuase como correa de transmisión de los principios que sostenían el orden político, que habría de prestarse a la labor de ideologización contrarrevolucionaria de los súbditos del rey, y que en lo material debería participar en el sostenimiento del esfuerzo bélico (de forma voluntaria, primero, y a petición de la propia Corona, después) con la aportación de importantes recursos. En la cooperación discursiva con la Corona el alto clero pudo contar, dada su familiaridad (armónica o conflictiva) con el ideario de las Luces, con un depósito teórico a partir del cual articular rápidamente una crítica global del proceso revolucionario. Obispos y arzobispos se unieron a la batalla contra los filósofos franceses y cumplieron con las demandas del gobierno para que pidieran a su grey que colaborase con los recursos necesarios, desoyese las máximas revolucionarias o mantuviese la paz social.

El alto clero parecía sumar con entusiasmo sus esfuerzos a los de la Corona en la guerra contrarrevolucionaria, pero la impresión puede ser engañosa. Sin descartar la existencia de ese afán cooperador, resulta evidente que el ideario desplegado por el episcopado en sus pastorales del periodo encierra una carga discursiva de notoria ambigüedad. En un nivel de lectura superficial, se revela en sus escritos la existencia de una renovada sinergia con la monarquía en la lucha contra la impiedad, el desorden y el regicidio. En estos términos se precisaban los discursos, digamos, oficiales. Sin embargo, bajo esta pátina discursiva se ocultaba, como muestra una lectura más atenta de los

\footnotetext{
55 RÚJULA, 2016.
} 
textos, la existencia de algunas fricciones en torno a la concepción misma del orden político. Ciertamente, el clima de guerra contra la Convención podía ser propicio a que el estado eclesiástico se prestara a sumar sus esfuerzos con los de la monarquía para actuar contra un enemigo común. Pero ese mismo ambiente permitía la crítica, en paralelo, de una expansión del poder del monarca que, en determinada lectura reaccionaria del siglo XVIII, podría encontrarse en el origen del mal revolucionario. En especial, según veremos, en lo que tocaba a su control del espacio eclesiástico o a los deseos de reforma eclesiástica promovidos sin concurso de la propia jerarquía clerical.

De hecho, es perceptible en algunos textos el establecimiento de cierto parentesco entre el devenir de los acontecimientos en Francia hasta la revolución con las críticas que se hicieron al regalismo en España desde los años sesenta del siglo XVIII. El regalismo, llevado más allá de sus justos límites, no solamente era considerado un ataque a la libertad eclesiástica, sino que repercutía directamente en la crisis de las bases constitutivas de la monarquía. El obispo de Calahorra retomaba el caso francés para explicar un proceso que debería hacer reflexionar a sus diocesanos: en su labor de erosión del orden monárquico, aquellos «falsos Filósofos» habrían asegurado, bajo pretexto de reforma de las estructuras eclesiásticas, «que la Religión Católica siempre sería la dominante», que tales reformas no afectarían sino a la organización material de la Iglesia y que la religión permanecería intacta, aunque al mismo tiempo «esparcían máximas de impiedad con más libertad que nunca» ${ }^{56}$. El mensaje era claro: bajo el pretexto regalista de protección a la Iglesia, se podía actuar contra la religión socavando, de paso, los fundamentos del edificio político.

Recordemos que la cooperación prestada por el alto clero durante la guerra contra la Convención se producía en un contexto de desarrollo crítico del proceso de acumulación del poder en el polo monárquico. La expansión de la capacidad de acción del monarca comportaba la marginación de otras instancias que estimaban tener una función consejera del poder político. Era el caso del alto clero, sí, pero no solamente; afectaba al conjunto del sistema. La expulsión de los jesuitas en 1767 o el progresivo control sobre las universidades (por citar las medidas de mayor impacto), marcan el punto álgido del desarrollo de una política regalista que envolvía aspiraciones de mayores vuelos. Los privilegios de los cuerpos o de los sujetos eran cada vez menos vistos, en la segunda mitad del siglo XVIII, como elementos constitutivos de la relación bilateral entre el rey y sus vasallos, pasando a considerarse, cada vez más, como prerrogativas arrancadas al monarca que este debía ir recuperando. Recuérdese que, si bien la expansión de la Corona tuvo su expresión más defini-

\footnotetext{
56 AGUIRIANO, 1793: 9-10.
} 
da en las pugnas por el sometimiento de la esfera eclesiástica al rey, la soberanía de este aspiró a extenderse no sólo al clero y a los cuerpos privilegiados, sino a las relaciones de parentesco, a la propiedad privada, a la transmisión de bienes, al mundo de la producción intelectual o al ámbito académico.

Con este telón de fondo, la irrupción del ciclo revolucionario francés puede ser vista como la ocasión de renovación de la sinergia entre las fuerzas veterorregimentales o, por el contrario, como catalizador y acelerador de tensiones preexistentes entre los componentes del sistema. En cierta manera, ambos fenómenos tuvieron lugar en la última década de la centuria. El momento fue propicio a la aclaración de ciertas dudas en torno a la progresión del poder regio, de su acaparamiento creciente del espacio político y de las consecuencias que esto pudiera tener. El obispo de Orense lo expresó con cierta nitidez cuando, en 1795, el arzobispo de Toledo contactó con él para que, junto con el resto del episcopado, cooperara al esfuerzo de la guerra donando la plata de las iglesias bajo su jurisdicción. En respuesta al primado, de 12 de febrero de 1795, exponía largamente varios puntos en los que, según pensaba, los cauces en los que se debían desarrollar las relaciones de la esfera política con la eclesiástica habían sido rebasados. Las exigencias monárquicas durante la guerra contra la Convención no serían sino la continuación de una línea de injerencia de largo recorrido que comenzaba a despertar la animosidad de una parte de las élites de la monarquía. Prefigurando la que sería su mejor conocida intransigencia ante las Cortes de Cádiz, el prelado de fino olfato político lanzaba una premonitoria declaración de desvinculación de la esfera eclesiástica al asegurar que los «Reyes, y los Reinos, se pierden sin la Iglesia. La Iglesia subsistirá siempre, y no depende de ellos» ${ }^{57}$. La bifurcación de los dos mundos, cuyas lógicas respectivas comenzaban a disociarse, era prevista de manera clara por el obispo.

Esa afirmación del obispo de Orense probablemente no se entienda en toda su dimensión sin una referencia al proceso de reafirmación de la autoridad pontificia sobre el mundo católico. En efecto, en las fechas en las que el prelado realizaba su reflexión, la Santa Sede iba haciendo significativos progresos en una concentración de poder paralela a la de la monarquía. Durante el siglo XVIII, ante las corrientes eclesiológicas que minoraban su importancia en el conjunto de la Iglesia universal (jansenismo, richerismo, episcopalismo, regalismo, galicanismo, josefinismo, etc.), Roma había ido promoviendo la idea de una única soberanía apostólica, poseedora de la plenitud de funciones (legislativa, disciplinar y magisterial) en la sociedad eclesiástica. Esta tendencia alcanzaba un punto álgido en su desarrollo a la altura de 1794 con la mencionada bula Auctorem fidei, condenatoria de las actas del sínodo de Pistoya, en la que pueden detectarse los elementos esenciales de la intransigencia cató-

57 Quevedo a Lorenzana. Orense, 12-II-1795. Citado en LÓPEZ-AYDILLO, 1918: 175-176. 
lica tal como se desarrollaría durante el siglo XIX ${ }^{58}$. La idea central de la bula, la de una sociedad eclesiástica en cuyo centro se situara la autoridad magisterial del pontífice romano, se había visto acelerada en su desarrollo por el ciclo revolucionario. No habría provocado este la ruptura neta con las controversias del pasado reciente sino su intensificación. El movimiento de afirmación pontificia había comenzado antes de los sucesos de Francia. Roma ya había ido desplegando diversas estrategias para contrarrestar los efectos disolventes de la modernidad temprana; estrategias que mostraron todo su potencial a la hora de enfrentarse a la revolución ${ }^{59}$.

En este proceso, las posiciones eclesiológicas de la denominada «escuela romana» (representada por E. D. Cristianopulo y T. M. Mamachi, P. Ballerini, F. A. Zaccaria o G. Bolgeni), cuyos ejes principales eran la idea de la monarquía pontifical y la de la infalibilidad pontificia, adquirieron una clara centralidad en la reflexión sobre la posición de la Santa Sede en el conjunto de la sociedad eclesiástica ${ }^{60}$. Esto fue complementado con una intensificación de prácticas piadosas y devocionales cuyo objetivo era la neutralización del jansenismo, tendente a la mitigación de tales prácticas en favor de un cristianismo depurado de ellas y, por extensión, de toda corriente que pretendiera atenuar la autoridad pontificia ${ }^{61}$. Durante el pontificado de Pío VI (1775-1799) se promovieron, asimismo, formas artísticas que compensaran la disminución de la autoridad política del papado maximizando su prestigio simbólico ${ }^{62}$. Y, frecuentemente de manera subrepticia, se difundieron al mismo tiempo obras favorables a los derechos de la Santa Sede por medio de las redes que, desde el secretariado de Estado pontificio hasta las nunciaturas, Roma tenía tejidas en Europa ${ }^{63}$.

Este proceso no puede ser minusvalorado si se quiere tener una idea cabal del pensamiento reaccionario posterior, en el cual la posición central del romano pontífice fue elemento destacable.

\section{LA ESPERANZA ULTRAMONTANA}

Roma saldría de su prudente inacción con respecto al proceso revolucionario tras la publicación de la Constitución Civil del Clero, que propiciaría la petición de intervención del papa por parte de la mayoría (todos excepto dos) de los

58 BOUTRY, 1994:59-82. NEVEU, 93/1 (1981): 215-275.

59 CAFFIERO, 2012.

60 REGOLI, 2006: 109-110, 117-121. FIORANI y ROCCIOLO, 2004: 394-400. PELLETIER, 2004: 235-257.

61 CAFFIERO, 2006.

62 COLLINS, 2005.

63 VANYSACKER, 1995: 266-271. 
obispos diputados en la Asamblea Nacional francesa, más cien eclesiásticos de la misma, que firmaron la Exposition des principes sur la Constitution Civil du Clergé dirigida a Pío VI. En el escrito, los prelados negaban a la Asamblea la legitimidad para intervenir en la esfera eclesiástica sin contar con el parecer previo de la Santa Sede y, lo que es más importante, pedían al papa que se pronunciara de una vez por todas sobre lo ocurrido desde el inicio de la revolución. El pontífice lo haría en marzo de 1791, con una diatriba contra la Asamblea, a la que acusaba de haberse arrogado poderes espirituales de manera ilegítima. Condenaba también en bloque la revolución, con lo que oficializaba el conflicto de esta con la Santa Sede ${ }^{64}$. De esto se desprendía una consecuencia importante: la jerarquía eclesiástica se veía obligada a elegir entre uno de los dos polos legitimadores concurrentes, sin que en adelante cupiera la doble lealtad que permitía la confianza en un poder secular tenido, en adelante, por potencialmente perverso (la Constitución Civil del Clero era entendida, de hecho, como consecuencia del desarrollo extremo del galicanismo ${ }^{65}$ ). Roma había conseguido, tras un largo periodo de mediación de la monarquía entre ambas partes, contactar directamente con los obispos galicanos a petición de estos. Y la urgencia del momento le permitiría soslayar todo obstáculo para marcar su supremacía sin mediación de los poderes seculares que en el Antiguo Régimen habían interferido, de mutuo acuerdo, en su contacto con el episcopado66.

Como percibiera Joseph de Maistre en su análisis retrospectivo de los acontecimientos, la Revolución francesa no podía tener sino un paradójico efecto positivo para la religión y, más concretamente, para la Santa Sede ${ }^{67}$. El ataque revolucionario servía a Roma una ocasión de oro para sustituir su paulatino debilitamiento político desde la paz de Westfalia por una renovada autoridad eclesiológica, doctrinal y carismática sobre el conjunto del mundo católico, tratando de establecer su hegemonía sobre una jerarquía eclesiástica universal que se había estado debatiendo entre dos potestades.

La trayectoria del arzobispo de Toledo (y, por ende, primado de España), Francisco Antonio Lorenzana, durante los últimos años de su vida es ilustrativa de los desequilibrios en la doble fidelidad en la que se había movido el episcopado hasta finales del siglo XVIII. Su caso nos servirá para adentrarnos en los inicios de un proceso de importantes consecuencias: la desvinculación de la jerarquía eclesiástica de la esfera política. Figura destacada del episcopado regalista durante el reinado de Carlos III, su antijesuitismo le había facilitado el nombramiento para el arzobispado de México en 1766. Estando a la

64 PELLETIER, 2004: 164-166. VANYSACKER, 1995: 254-255.

65 Como resulta, por ejemplo, de la interpretación de los hechos del cardenal Giuseppe Garampi, VANYSACKER, 1995: 256-258.

66 PELLETIER, 2004: 333-360.

67 ARMENTEROS, 2013: 67-68. GENGEMBRE, 1989: 253-255 
cabeza de este organizó el (mal) llamado IV concilio provincial mexicano, en el cual actuó como portavoz de los intereses de la Corona en varios asuntos que interesaban a esta. Su comportamiento le valdría la promoción a la sede primada de España en 1772. Ejemplo paradigmático, a priori, de sujeción al regalismo carlotercista, su pensamiento no puede reducirse, como veremos, a categorías predefinidas o estereotipos historiográficos ${ }^{68}$. Su interés reside, precisamente, en su aparente ambigüedad.

Francisco Antonio Lorenzana es en ocasiones definido como uno de los representantes del alto clero ilustrado, junto con José Climent o Antonio Tavira. Si no queremos vaciar completamente de contenido el calificativo, describiendo bajo su paraguas actitudes bien distintas ante las Luces, hay que precisar mínimamente su significado. Sus inclinaciones regalistas, su participación de algunas de las empresas reformistas del periodo, su inquietud intelectual o la promoción de una mejor formación clerical no necesariamente han de corresponderse sin más con una actitud ilustrada. De hecho, su temprana hermenéutica de los acontecimientos de Francia como obra de la filosofía marca bien a las claras su rechazo de las manifestaciones más radicales de la Ilustración ${ }^{69}$. Esa actitud no era fruto de un súbito horror. Se encontraba bien anclada en la manera de ver el mundo del primado y, de hecho, es necesario profundizar en ella para comprender su recorrido posterior.

Su idea sobre la estructuración de la Iglesia (de amplia influencia sobre su concepción de lo político), resulta reveladora. En 1776 compendiaba, en carta al padre Ceballos, los puntos más importantes de su pensamiento eclesiológico. En síntesis, subrayaba la importancia clave del concepto de jerarquía en la Iglesia. Para él, jansenistas y todo tipo de novadores eran enemigos potenciales de este principio, al cuestionar la jerarquía o proponer nuevas formas de organización eclesiástica. Las propuestas venidas del flanco jansenista equivalían a «desconceptualizar al Vicario de Cristo en la tierra, minorar el respeto al episcopado, ensalzar la libertad de las costumbres» ${ }^{70}$. Tres años antes, en representación escrita a Carlos III en 1773, desaprobaba con fuerza el conciliarismo, idea característica de la eclesiología jansenista y episcopalis-

68 Como acertadamente indican SAUGNIEUX, 1976: 247-278, y VIZUETE, 2004.

69 Eso se desprende de la respuesta dada por José Nicolás Azara, embajador en Roma, al arzobispo, en 21 de octubre de 1789, en la que le decía: «Usted declama contra la filosofía como autora de los males de Francia, y yo no soy de su sentir. La buena filosofía siempre hace bien y nunca mal. La corrupción de las costumbres, el mal gobierno, la dilapidación del Estado, el descrédito de los que mandan, y la ambición loca de los que no son filósofos han traído esta revolución». AZARA, 2010: doc. 67. Se reafirmaría en la misma idea al ser testigo de la llegada de los obispos franceses emigrados en España, hecho que terminaría por convencerle de que lo que estaba ocurriendo en el reino vecino era resultado de los excesos de la filosofía (GUTIÉRREZ, 20, 1993: 168).

70 SAUGNIEUX, 1976: 271-275. VIZUETE, 2004: 338-356. 
ta, por considerar que aminoraba la autoridad del papa $^{71}$. Hay que tener en cuenta al señalar esta idea, que en los primeros tiempos de la Contrarreforma se había apuntalado la tesis de que dicha corriente estaba en el núcleo de las conmociones vividas en la Iglesia durante el siglo XVI ${ }^{72}$. Con esto, el primado venía a señalar implícitamente que cualquier atisbo de alteración de la jerarquía eclesiástica repercutiría, también, en el sistema político. En resumen, según su modo de ver las cosas, el marco ideal de coexistencia de las dos potestades era el que otorgaba a los príncipes católicos el papel de protectores de la Iglesia en sus dominios; eso sí, con el respeto mutuo de ambas esferas. El desequilibrio en favor de alguna de las dos rompería inevitablemente el marco.

Su correspondencia privada con el jesuita expulso Faustino Arévalo, antiguo profesor del colegio de la Compañía de Jesús en Medina del Campo y relevante humanista de prolífica producción bibliográfica residente en Italia, ofrece una privilegiada ventana para captar los desarrollos posteriores de estos postulados. El primado, en un elocuente giro de su antijesuitismo previo, había establecido contacto (a través de su secretario de cámara), a finales de los años 80 o comienzos de los 90, con Faustino Arévalo, cuyos escritos patrocinaría en adelante. En las cartas enviadas desde Roma por este entre 1793 y 1796, publicadas por Rafael Olaechea, se pueden encontrar noticias sobre temas tanto eruditos, como eclesiásticos o políticos. Constituyen un formidable material para la observación de su acercamiento a realidades que superaban la monarquía hispánica (en la que se había movido principalmente hasta entonces), de la forja de una nueva visión de los acontecimientos en aquella cambiante Europa, de su inserción progresiva en el entorno de un incipiente ultramontanismo global o de su percepción de los cambios en los que se encontraba inmerso el mundo que había conocido ${ }^{73}$.

El patrocinio del primado sobre la obra de Faustino Arévalo comportaba la aceptación, al menos parcial, de los presupuestos ideológicos de este. La relación, que llegó a ser estrecha, superaba lo meramente erudito para insertarse de lleno en el combate contrarrevolucionario. Eran dos aspectos inextricables. Especialmente cuando, como decía el exjesuita, las circunstancias exigían que no solamente las armas, sino también los libros «se emplearan en combatir la impiedad corriente ${ }^{74}$. El mundo de los jesuitas expulsos en Italia se había constituido en un foco de investigación de primera magnitud en humanidades, reconocido como tal incluso por los sectores que con más ahínco habían luchado contra la Compañía y que todavía guardaban una clara actitud contraria

71 LORENZANA, 1773: 384.

72 PRODI, 2011: 19-20.

73 Tema tratado con mayor detalle en ARTOLA, 2013: 199-210.

74 F. Arévalo a F. A. Lorenzana. Roma, 2-X-1794. OLAECHEA, LI (1982): 138. 
sobre lo que esta había representado. Los expulsos formaban un grupo en que se daban cita, por una parte, la defensa de la eclesiología ultramontana y, por la otra, las pautas características de deseo de descubrir nuevas realidades, de intensa investigación, que se han atribuido a cierta Ilustración, todo ello en armónico equilibrio ${ }^{75}$. Es significativo que, entre los materiales que el exjesuita enviaba al primado figuraran (además de los correspondientes a sus intereses eruditos) ejemplares del Giornale ecclesiastico di Roma, publicación pontificia de combate opuesta a los Annali ecclesiastici, impresos en Florencia, de corte jansenista ${ }^{76}$.

La comunidad de intereses intelectuales adquiría con el contexto revolucionario una nueva dimensión. En este sentido, si los «buenos libros» que, entre ambos, iban publicando, servirían para complementar en un nivel intelectual la lucha física en la guerra contra la Convención, el nombramiento del cardenal para Inquisidor General mostraba «la singular piedad, y prudencia» del rey, quien, «honrando el estado eclesiástico, se opone directamente a las impías máximas de los que quieren deprimirle, para introducir de este modo la irreligión y la anarquía» ${ }^{77}$. Junto a las cuestiones técnicas o logísticas de la colaboración literaria, iban apareciendo señales evidentes de la introducción de nuevos conceptos, expresados en el lenguaje de una incipiente modernidad contrarrevolucionaria ${ }^{78}$. La Revolución francesa, con sus consecuencias sobre las relaciones de poder en la sociedad del Antiguo Régimen, cobra una importancia cada vez mayor en la correspondencia a medida que los acontecimientos se van sucediendo. Las informaciones enviadas por el exjesuita daban cuenta del trastorno integral que conllevaba el proceso revolucionario en los lugares en que conseguía derribar al antiguo orden. Es lo que, según relataba Arévalo, ocurría en Milán tras la llegada de los revolucionarios: nobles decapitados, un abogado al frente del gobierno, un calendario de nueva creación marcaban, en la mentalidad discursiva del exjesuita, la sustanciación de un proceso cuyos fundamentos no eran compatibles con los que sostenían el edificio social, institucional y político en la Europa católica hasta 178979 .

Esta comunicación con Roma, que mostraba al cardenal la situación de la Iglesia universal, el desarrollo de la guerra contra Francia y el hundimiento del sistema veterorregimental, se complementaba e intersectaba con muchas otras cartas, en que se expresaban cambios profundos en lo político, en lo

75 Entre la bibliografía al respecto, destacan GUASTI, 2006; GUASTI, 123 (2009). GIMÉNEZ y FERNÁNDEZ, 2010. GIMÉNEZ, 15 (1996).

76 Arévalo a Martínez Nubla. Roma, 31-VII-1794. OLAECHEA, LI (1982). Sobre el Giornale Ecclesiastico di Roma, VANYSACKER, 1995: 271-272.

77 Arévalo a Lorenzana. Roma, 14-VIII-1794. OLAECHEA, LI (1982): 140.

78 BATLLORI, 1966: 84-86.

79 Arévalo a Lorenzana. Roma, 1-VI-1796. OLAECHEA, LI (1982): 151. 
eclesiástico, y la disociación paulatina de ambos mundos. La multitud de misivas que le enviaban clérigos franceses refugiados en España constituyen un buen ejemplo ${ }^{80}$. Por su condición de primado, mediador del episcopado español con la Corona, era por otra parte centro receptor de las impresiones de los obispos españoles sobre la Revolución francesa, sobre su relación con el poder político y sobre la experiencia de la guerra. Como las del obispo de Orense, con el que, a pesar de todo lo que les pudiera separar, coincidía en la transcendental importancia del proceso en que estaban inmersos, ellos, y el mundo católico en general. En respuesta a las cartas en que aquel mostraba su reticencia a donar la plata de las iglesias para el sufragio de la guerra contra Francia, argumentando la falta de correspondencia entre el uso de los bienes de la Iglesia (que deberían ir a parar a los pobres) y los objetivos de la guerra (que incumbían a los reyes), el primado contestaba con un lenguaje que muestra la consolidación de determinados conceptos e ideas. Haciendo un repaso de algunos acontecimientos que habían precedido a la revolución, afirmaba que en la Historia de la Iglesia no había habido «guerra más universal, más sangrienta, y declarada con igual empeño que la que al presente hacen los Filósofos ateístas de la Francia», quienes «hacen la ostentación de decir que no hay Dios, y burlarse de toda Religión verdadera». La correspondencia de Federico de Prusia con Voltaire mostraba que «entre los dos se trataba de los medios de acabar con la Religión, y que sus pronósticos ya se han verificado en la Francia», siendo el siguiente paso el de «esparcir el veneno a nuestras provincias» ${ }^{81}$

La asunción de los principios complotistas del mito reaccionario europeo aparece bien representada en estas frases. Existían, parecía decir el primado, en la sombra, fuerzas ocultas que habían movido a la masa popular a tomar las armas contra el orden, empujadas básicamente por los filósofos ateos franceses. El proyecto de las élites impías veía cómo se realizaban algunos de sus puntos en la Revolución francesa. Cabe recordar que estas ideas eran muy conocidas entre los exjesuitas españoles residentes en Italia, de cuyas mejores plumas salió la formulación más acabada del mito ${ }^{82}$. Puede que la inserción progresiva de Francisco Antonio Lorenzana en las redes epistolares de aquel mundo le ofreciera (o le confirmara), algunas claves de interpretación del contexto político global.

El creciente contacto con estas realidades forzosamente había de tener consecuencias en sus relaciones con la Corona. De hecho, lo eclesiológico adquirió una evidente dimensión política en la última década del siglo ${ }^{83}$. La

80 GUTIERREZ, 2004: 398-427.

81 Lorenzana a Quevedo. Madrid, ¿?-II-1795. Cit. LÓPEZ-AYDILLO, 1918: 177-178.

82 HERRERO, 1971: 151-180. GIMÉNEZ, 2010.

83 LA PARRA, 2 (2001-2002). 
tendencia a la intensificación expansiva que la monarquía siguió en estos años era exactamente la contraria a la que, según una fracción de las élites de la monarquía entre las que se encontraba el primado, había que adoptar tras los acontecimientos en Francia. En lo que hace a la relación de la Corona con la jerarquía eclesiástica, los incidentes que tuvieron lugar en 1793 entre el arzobispo de Valencia (amigo de largo recorrido de Francisco Antonio Lorenzana) y el capitán general de aquel reino (duque de la Roca), con el resultado de la renuncia forzada del primero a la mitra, venían a dejar claro que el episcopado estaba viéndose sujeto por la monarquía ${ }^{84}$. La utilización de las regalías de mayor relevancia se consolidó durante la última década de la centuria, como mostraba el uso del exequatur o «pase regio» para evitar la circulación (contra los deseos del primado, que trabajó intensamente por su publicación) de la bula Auctorem fidei, en la que se criticaba la intervención unilateral del poder político sobre las estructuras eclesiásticas. Constantemente se dictaron disposiciones para regular asuntos tocantes a lo eclesiástico, desde el destino de las rentas episcopales a la creación de capellanías.

El primado, que marchaba en el sentido contrario al de esta evolución absolutista, se estaba convirtiendo en un problema. En la sesión del Consejo de Estado de 29 de diciembre de 1795 lanzó una contundente amonestación al gobierno por su supuesta permisividad en la difusión de obras extranjeras que «extendían el veneno de la libertad e igualdad» mientras el poder de actuación de la Inquisición (a cuya cabeza se le había puesto confiando en su docilidad regalista) era coartado ${ }^{85}$. Su insistencia en la condenación del sínodo de Pistoya y, más tarde, sus esfuerzos para la publicación de la bula Auctorem fidei, le aproximaban al conflicto abierto con el poder político. Por último, fuentes diplomáticas francesas situaban a Lorenzana en el partido de oposición a Manuel Godoy (indistintamente denominado «aragonés», «inglés», o «aristocrático»), confluencia de aristócratas y jerarcas eclesiásticos, junto con un amplio grupo de canónigos y otros clérigos a los que se conocía como grupo beato. Ese partido habría tenido como objetivo, desde 1794, poner fin a la guerra con Francia, y organizar el gobierno interior acortando el campo de influencia del rey, revitalizando la estructura de los Consejos en detrimento del secretario del despacho de Estado ${ }^{86}$. La presencia del primado en España podía entorpecer tanto la planeada alianza con Francia como los proyectos de amplia reforma eclesiástica que barajaba la Corona.

En estas circunstancias fue enviado a Roma, en marzo de 1797, en una embajada extraordinaria junto con el confesor de la reina María Luisa (Rafael Múzquiz) y el arzobispo de Sevilla (Antonio Despuig), con el supuesto obje-

\footnotetext{
84 LEÓN, 2003.

85 LA PARRA, 1992: 58.

86 LA PARRA, 1992: 110.
} 
tivo de asistir al papa tras la primera invasión de la ciudad por los franceses. En realidad se trataba de un destierro. En marzo de 1798, contraviniendo las órdenes del Príncipe de la Paz, proyectaba volver a España; decisión que tuvo que revocar por la orden de quedarse en Roma como embajador ${ }^{87}$. Más tarde, cuando se le exigió volver, en 1800, se negó a hacerlo. Permaneció en la Ciudad Eterna, eligiendo a Faustino Arévalo como su secretario de cámara. Desde 1801 trabajaría en el marco de la congregación cardenalicia de Propaganda fide integrándose plenamente en el colegio cardenalicio, en el cual desarrolló nuevas actividades, amistades y, seguramente, una nueva forma de entender qué era, cómo se debía estructurar y cuál era el papel de la Iglesia en aquel convulso mundo ${ }^{88}$.

En sus últimos días, habría mirado hacia la Santa Sede en busca de una legitimidad que reconociera su posición. En abril de 1804 murió en Roma y con él moría, también, en cierta medida, todo un conjunto de concepciones sobre la coexistencia armónica de las dos potestades. Su caso no puede ser explicado con el sencillo recurso al desengaño del antiguo regalista. Lo que revela es una rápida erosión de las bases sobre las cuales se fundamentaba la entente entre ambas potestades. Eliminados estos fundamentos, la jerarquía eclesiástica iniciaba el camino hacia una separación del mundo político, dotado de una eclesiología que minorara la importancia de la razón en favor de la intuición, la emoción y el sentimiento comunitario, en una sociedad eclesiástica organizada en torno al primado pontificio ${ }^{89}$.

\section{CONCLUSIONES}

El ultramontanismo, el rechazo visceral de la Ilustración y la intransigencia doctrinal es solamente uno de los resultados posibles del posicionamiento del clero al alborear el siglo XIX. Se suele dar demasiado por supuesta una intransigencia natural de la Iglesia que conviene al finalismo con el que se ha escrito la historia de aquel siglo. A lo largo de este trabajo hemos estudiado las diferentes versiones de la reacción eclesiástica española a la Revolución francesa, demostrando que la historiografía, siguiendo la estela de Javier Herrero, ha incurrido en una excesiva generalización a la hora de situar a la práctica totalidad de los autores en una posición oscurantista y como meros reproductores del pensamiento antifilosófico europeo de los años 1770-1780.

87 OLAECHEA, 1980: 163.

88 REGOLI, 2006: 197, 272-277, 314-317, pueden verse las actividades de Lorenzana en el cónclave de 1799-1800, así como sus relaciones con otros cardenales y su reconocida posición en la corte pontificia.

89 Como indica LEHNER, 2016: 214-216. 
Creemos, en cambio que distintos contextos han de dar lugar, a la fuerza, a distintas expresiones. Diferente fue la especulativa y bastante independiente Ilustración francesa de la pragmática y tutelada Ilustración española, igual que fue distinta la situación política a un lado y al otro del Pirineo a partir de 1789. Tampoco - y coincidimos con López Alós - parece acertado hacer del padre Ceballos y sus seguidores una secta de aislados oscurantistas ${ }^{90}$. Incluso el propio monje, al que no podemos llamar amigo de las Luces precisamente pero que era hijo de su tiempo, tuvo que negociar con ellas en la dedicatoria a Campomanes de su Falsa filosofía o en el plan de reforma de las universidades que haría llegar a Godoy más tarde para intentar salir del ostracismo.

Se puede decir que los dos primeros epígrafes de este artículo estudian a los ideólogos religiosos que hicieron causa común con el poder, si bien cada uno lo hizo de acuerdo a sus circunstancias y a su bagaje previo. Por el contrario, los dos últimos recogen la existencia de un sentimiento de desafección clerical hacia la monarquía, cuyo absolutismo regalista era una amenaza constante para la Iglesia, cuyo proyecto reformista tendía en ocasiones peligros puentes a las ciencias y las Luces y cuyas necesidades en política exterior la habían acabado acercando a la Francia republicana.

Desde este punto de vista, el de la desafección eclesiástica al absolutismo ilustrado, que se manifestaría en el apoyo clerical a Fernando VII en el golpe de Estado de Aranjuez o en la posterior militancia carlista de los sectores más conservadores de la Iglesia, se puede hacer una doble lectura de varios de los sermones y tratados que apoyaron al trono en 1793. Si estamos de acuerdo en que los elogios fúnebres de Jovellanos y Cabarrús al supuesto mecenas de las Luces, Carlos III, no presentaban a la monarquía como era, sino como estos autores querían que fuera, i,podríamos hacer una doble lectura de los textos de Villanueva o Vila y Camps en esa misma línea? ¿Permiten las defensas religiosas del trono una doble lectura apologética pero crítica (o nostálgica) al mismo tiempo?

En todo caso, creemos que es importante introducir el desencanto con el absolutismo en la ecuación contrarrevolucionaria del Ochocientos español. El progreso del ultramontanismo daría forma al pensamiento reaccionario del siglo que comenzaba. El concordato de 1801 con Francia fortaleció de manera considerable a la Santa Sede. La prisión de Pío VII contribuyó, más tarde, a hacer de la figura pontificia un mártir viviente, con toda la carga simbólica que ello conllevaba. La mayoría del alto clero católico (del que quedaban excluidos, en la era postrevolucionaria, regalistas, episcopalistas, jansenistas e ilustrados) iba situándose en la obediencia univoca e incondicional al pontífice romano, devenido centro de autoridad exclusivo del catolicismo. La tor-

\footnotetext{
90 LÓPEZ ALÓS, 2011: 35-37.
} 
menta revolucionaria, si bien acabó de debilitar definitivamente el rol político del papado, que no podía sumarse a la modernidad sin sacrificar sus rasgos constitutivos más elementales, tuvo como efecto hacer de la Santa Sede el refugio simbólico, sentimental y carismático de aquellos sectores que rechazaban el diálogo con la modernidad pero que tampoco se sentían identificados con el absolutismo regalista. El ultramontanismo ofrecía a estos sectores una cosmovisión coherente, consistente e integral al margen de las convenciones políticas modernas fundamentadas en la supremacía de la razón. Y como tal, fue en todo el mundo católico nicho recurrente de generaciones de reaccionarios que, como Joseph de Maistre, se negaban a aceptar (por mucho que las revoluciones demostrasen lo contrario) que la producción de lo político correspondiese a los hombres en vez de a la divinidad ${ }^{91}$.

\section{FUENTES PRIMARIAS}

Aguiriano, Francisco Mateo, Carta que dirige (...) con motivo de la presente guerra con la Francia, Logroño, Imp. Antonio José Delgado, 1793.

Azara Perera, José Nicolás, Epistolario (1784-1804), Madrid-Zaragoza, Castalia / Institución Fernando el Católico, 2010, estudio, edición y notas de María Dolores Gimeno Puyol.

Cádiz, Fray Diego José de: El soldado católico en guerra de religión, Écija, Benito Daza, 1794.

Ceballos, fray Fernando, La falsa filosofia, Madrid, Sancha, 1774-1775, 6 vols.

Ceballos, Fernando: «Remedio permanente del estado peligroso en que actualmente se hallan las Universidades, Colegios, Academias, y Estudios Generales, o particulares de España», en Robledo, 2012.

El ciudadano imparcial, 1813.

Dorca, Francisco, Verdadera idea de la sociedad civil, Gerona, Vicente Oliva, 1803a.

Dorca, Francisco, De las ventajas del gobierno monárquico, Gerona, Vicente Oliva, $1803 b$.

Eximeno, Antonio: «Disertación sobre el valor militar en defensa de la religión cristiana», en El espiritu de Maquiavelo ..., Valencia, Benito Monfort, 1799, pp. 70-95.

Fernández de Valcárcel, Vicente, Desengaños filosóficos, Madrid, Blas Román, 1787-1797, 4 vols.

Lorenzana, Francisco Antonio, «Representación reservada al rey sobre varios puntos importantes» (Toledo, 27-X-1773), en Gutiérrez García-Brazales, 2004, pp. 379-386.

Peñalosa, Clemente, La Monarquía, Madrid, Imprenta Real, 1793.

Sánchez Sobrino, Sebastián, El vasallo fiel a su príncipe, Madrid, Plácido Barco López, 1798.

91 ARMENTEROS, 2013: 29-30. 
Tavira, Antonio, «Informe dado al rey y dirigido al señor Príncipe de la Paz (1797)», en Saugnieux: 133-145.

Tavira, Antonio, «Carta pastoral del 4 de junio de 1801», en Saugnieux, pp. 172-176.

Villanueva, Joaquín Lorenzo, Catecismo del Estado según los principios de la religión, Madrid, Imprenta Real, 1793

\section{BIBLIOGRAFÍA}

Albertan-Coppola, Sylviane (dir.), Christianisme et Lumières; número monográfico de la revista Dix-Huitième Siècle, 34, 2002.

Armenteros, Carolina, L'idée française de l'histoire; Joseph de Maistre et sa postérité (1794-1854) [The French Idea of History: Joseph de Maistre and His Heirs, 1794-1854], Paris [New York], Classiques Garnier [Cornell University Press], 2013 [2011].

Artola, Andoni, De Madrid a Roma. La fidelidad del episcopado en España (17601834), Gijón, Trea, 2013.

Batllori, Miguel, La cultura hispano-italiana de los jesuitas expulsos: españoles, hispanoamericanos, filipinos: 1767-1814, Madrid, Gredos, 1966.

Bono Guardiola, Ma José, «La defensa del absolutismo en La Monarquía de Clemente Peñalosa», Revista de Historia Moderna, 13/14 (1995), pp. 313-340.

Boutry, Philippe, «Tradition et autorité dans la théologie catholique au tournant des XVIII $^{\mathrm{e}}$ et XIX ${ }^{\mathrm{e}}$ siècles. La Bulle Auctorem fidei (28 août 1794)», en Jean-Dominique Durand (dir.), Histoire et théologie, Paris, Beauchesne, 1994, pp. 59-82.

Caffiero, Marina, «La construcción de la historia del papado en la Edad Moderna a través de la historiografía de sus ceremonias y rituales», en Atienza López, Ángela (ed.), Iglesia memorable. Crónicas, historias, escritos... a mayor gloria. Siglos XVI-XVIII, Madrid, Sílex, 2012, pp. 51-70.

Caffiero, Marina, La fabrique d'un saint à l'époque des Lumières, Paris [Roma / Bari], Editions de l'EHESS, 2006 [1996].

Calvo Maturana, Antonio, “Aquel que manda las conciencias”: Iglesia y adoctrinamiento político en la Monarquía Hispánica preconstitucional (1780-1808), Cádiz, Fundación Municipal de Cultura, 2011.

Calvo Maturana, Antonio, «¿Una contrarrevolución ilustrada?: Fray Sebastián Sánchez Sobrino y la cara iluminada del pensamiento reaccionario español», en Rújula, Pedro y Ramón Solans, Javier (eds.): El desafio de la Revolución. Reaccionarios, antiliberales y contrarrevolucionarios (siglos xviii y xix), Granada, Comares, 2017, pp. 283-299.

Chappey, Jean-Luc, Les anti-lumières et les oppositions intellectuelles à la Révolution», en Jean-Clément Martin (dir.), La Révolution à l'ouvre. Perspectives actuelles dans l'histoire de la Révolution française, Rennes, PUR, 2005, pp. 165-180.

Collins, Jeffrey, Papacy and Politics in Eighteenth-Century Rome. Pius VI and the Arts, Cambridge, Cambridge University Press, 2004. 
Compagnon, Antoine, Les antimodernes. De Joseph de Maistre a Roland Barthes, Paris, Gallimard, 2005.

Conde Naranjo, Esteban, El Argos de la monarquía: la policía del libro en la España ilustrada (1750-1834), Madrid, CEPyC, 2006.

Fiorani, Luigi y Rocciolo, Domenico, Chiesa romana e rivoluzione francese, 1789 1799, Roma, École Français de Rome, 2004.

Fureix, Emmanuel, Le siècle des possibles. 1814-1914, Paris, PUF, 2014.

Fureix, Emmanuel; Jarrige, François, La modernité desenchantée. Relire l'histoire du XIXe siècle français, Paris, La Découverte, 2015.

Gengembre, Gérard, La Contre-révolution ou l'histoire désespérante, Paris, Editions Imago, 1989.

Giménez López, Enrique, «Los jesuitas y la teoría de la conspiración», en Giménez López, Enrique (ed.), Aspectos de la Política Religiosa en el siglo XVIII: Estudios en Homenaje a Isidoro Pinedo Iparraguirre, S. J., Alicante, Universidad de Alicante, 2010, pp. 251-280.

Guasti, Niccolò, «Rasgos del exilio italiano de los jesuitas españoles», Hispania Sacra, 123 (2009), pp. 257-278.

Guasti, Niccolò, Lotta politica e riforme all'inizio del regno di Carlo III. Campomanes e l'espulsione dei gesuiti dalla monarchia spagnola (1759-1768), Firenze, Alinea Edictrice, 2006, 416 p.

Gutiérrez García-Brazales, Manuel, El exilio del clero francés en España durante la Revolución (1791-1815), Zaragoza, 2004.

Herrero, Javier, Los orígenes del pensamiento reaccionario español, Madrid, Cuadernos Para el Diálogo, 1971.

La Parra, Emilio, La alianza de Godoy con los revolucionarios (España y Francia a finales del siglo XVIII), Madrid, CSIC, 1992.

Lehner, Ulrich D., Catholic Enlightenment. The Forgotten History of a Global Movement, New York, Oxford University Press, 2016.

López Alós, Javier, Entre el trono y el escaño. El pensamiento reaccionario español frente a la revolución liberal (1808-1823), Madrid, Cortes Generales, 2011.

López-Aydillo, Eugenio, El obispo de Orense en la Regencia del año 1810 (planteamiento de los problemas fundamentales de la vida constitucional de España), Madrid, Centro de Estudios Históricos, 1918.

López-Cordón Cortezo, $\mathrm{M}^{\mathrm{a}}$ Victoria, «Predicación e inducción política en el siglo XVIII: Fray Diego José de Cádiz», Hispania, 38 (1978), pp. 138-171.

Maire, Catherine, De la cause de Dieu à la cause de la Nation. Le jansénisme au XVIIIe siècle, Paris, Gallimard, 1998.

Masseau (Didier), Les ennemis des philosophes. L'antiphilosophie au temps des Lumières, Paris, Albin Michel, 2000.

Mazauric, Claude, «Autopsie d'un échec: la résistance à la Révolution et la défaite de la Contre-Révolution», en Roger Dupuy y François Lebrun (dir.), Les résistances à la Révolution, Paris, IImago, 1987, pp. 237-244. 
McMahon, Darrin M., Enemies of the Enlightenment: the French CounterEnlightenment and the making of modernity, New York, Oxford University Press, 2001.

Neveu, Bruno, «Juge suprême et docteur infaillible: le pontificat romain de la bulle "In eminenti" (1643) à la bulle "Auctorem fidei"» (1794)», Mélanges de l'Ecole française de Rome. Moyen-Age, Temps modernes, 93/1 (1981), pp. 215-275

Olaechea, Rafael, «El Cardenal Lorenzana y los ex jesuitas (Arévalo, Masdeu, Luengo, Bolgeni). Cartas de Arévalo a Lorenzana (1793-1796)», Archivum Historicum Societatis Iesu, LI (1982), pp. 80-160.

Olaechea, Rafael, El cardenal Lorenzana en Italia (1797-1804), León, Institución Fray Bernardino de Sahagún-CSIC, 1980.

Pelletier, Gérard, Rome et la Révolution française: la théologie et la politique du SaintSiège devant la Révolution française, Roma, École Française de Rome, 2004.

Pocock, John Greville Agard, «Enlightenment and counter-enlightenment, revolution and counter-revolution: a eurosceptical inquiry», History of Political Thought, 20/1, (1999): 125-139.

Portillo Valdés, José María, Revolución de nación: orígenes de la cultura constitucional en España, 1780-1812, Madrid, CEPyC, 2000.

Prodi, Paolo, El soberano pontífice. Un cuerpo y dos almas: la monarquía papal en la primera edad moderna, Madrid, Akal, 2011 [Roma, 1982].

Ramón Solans, Francisco Javier, «Conjugando los tiempos presentes. Figuras temporales de la Contrarrevolución española (1789-1814)», Historia y política, 28 (2012), pp. 215-243.

Regoli, Roberto, Ercole Consalvi: le scelte per la Chiesa, Roma, Editrice Pontificia Università Gregoriana, 2006.

Robledo, Ricardo, «El Padre Ceballos, ¿”humilde capellán” de Godoy? El Plan de universidades de 1796», Trienio: Ilustración y Liberalismo, 59 (2012), pp. 65-115.

Robledo, Ricardo, «Las Dos España de 1796: la Universidad del fraile Ceballos y la de Forner», en Gimeno, M ${ }^{\mathrm{a}}$ Dolores y Viamonte, Ernesto, eds.: Estudios dieciochistas en homenaje a María Dolores Albiac Blanco, Zaragoza, IFC, 2015, pp. 219-236 / 223).

Rújula, Pedro, «Patriotisme monarchique et pouvoir absolu pendant la Guerre d'Espagne contre la Convention (1793-1795)», Siècles. Cahiers du Centre d'Histoire Espaces et cultures [en línea], 43 (2016).

Saugnieux, Joël (ed.): La Ilustración católica en España. Escritos de D. Antonio Tavira, obispo de Salamanca (1737-1808), Salamanca, Universidad de Salamanca, 1986.

Sierra Nava, Luis, El cardenal Lorenzana y la Ilustración, Madrid, Fundación Universitaria Española, 1975.

Sternhell, Zeev, Les anti-lumières. Du XVIIIe siècle à la guerre froide, Paris, Fayard, 2006.

Valverde Tercedor, José María, «El ministro de Carlos IV, Francisco de Saavedra. Formación y vínculo con Granada», Tiempos Modernos, 30, 1 (2015), pp. 1-24 
Vanysacker, Dries, Cardinal Giuseppe Garampi (1725-1792). An Enlightened Ultramontane, Bruxelles / Rome, Institut historique Belge de Rome, 1995.

Vizuete Mendoza, José Carlos, «Sobre la Ilustración y el regalismo del cardenal Lorenzana», en Fernando Llamazares y José Carlos Vizuete (coords.): Arzobispos de Toledo, mecenas universitarios, Cuenca, Universidad de Castilla-La Mancha, 2004, pp. 346-348.

Zaganiaris (Jean), «Qu'est-ce que les “contre-lumières"?», Raisons politiques, 35 (2009), p. 167-183.

Recibido: 26/05/2016

Aprobado: 07/03/2017 